\title{
AESTHETICS IN ARCHITECTURE: CONTEMPORARY RESEARCH ISSUES
}

\author{
A B S T R A C T
}

The aim of this article is to provide an overview regarding research into aesthetic issues concerning architecture, urban design, and environment in general. For this purpose, the article focuses on the period of the last twelve years, as a period of intensive research into the named issues using new philosophical positions and values of interculturality. It seems that in that period research in aesthetics of architecture shifted into complex interdisciplinary fields developing new theoretical ideas enriching at the same time processes of creative practice. 
Contemporary ideas on issues regarding aspects and principles of aesthetic thinking in/on architecture are mainly developing according to the theoretical, philosophical, and inter/cultural views of the last few decades of the twentieth century. The more interesting point is that these views liberated scholars from thinking on aesthetics in architecture based on the strict nominal values regarding principles of "gestalt" theory. Once being the primal field of investigation what creates the absolute universal concept of beauty in architecture, as the research in proper proportions, or in the theory of form in general and particularly suitable for various functions, or what makes the artistic concept forming a city, vanished. Even the issues regarding empathy and other concepts of creativity and aesthetic evaluation of this kind developed in the first half of the twentieth century, do not hold strongly in new discussions on architecture and our built environment.

This position shifted the interest of researchers and scholars into the field of experimentation and theoretical speculation, incorporating into discussion on architecture and urban design broader issues from a variety of different disciplines. A number of new notions regarding the aspects of creativity, perception, and evaluation of architectural and urban design and their social and cultural role emerged. The close collaboration between philosophers and architects in the last quarter of the twentieth century opened that possibility, and redefined many aspects and principles on which the discipline of building has been based. This pervasion of philosophy, architecture, and urban design brought up ideas and notions which the international modernism band from the theoretical exploration and practice. Many ideas and approaches to the essence of man's perception of architecture as a complex environment, which have been developed by the avant-garde movements on the beginning of the twentieth century came back into the focus of the scholars and architects. We can say that dynamic of contemporary life turned back into the creativity of architects and urban designers, however sometimes in a way which challenge the essence of our previous understanding what these fields of human activity are.

This dynamic vision and practice of architecture and urban development generated new ideas and notions what the aesthetics linked to them can be. When Derrida and Baudrillard, for example, paid their attention on architecture and urban environment as a cultural phenomenon of the time, the definition of aesthetic aspects regarding their contemporary value shifted into the new speculative field. No more form defined by functional dictate, but anticipated dynamic activity of the user-participant; no more perceptual solidity of form 
and cultural meaning, but the notion of aesthetics of disappearance and fluid perceptual qualities. That brought old issues into new focus, and the redefinition of aesthetic values in architecture and urban environment took over. From the 'perfectly' formed object, architecture become interpreted as a cultural performance with various functions and meanings; from the artistically formed whole, urban structure become a dynamic environment mirroring contemporary cultural, technological, and commercial activities. New aesthetic terms and vocabulary has been established, becoming a driving force of research in new phenomenon and understanding what the perception and experience of space and form, space and human body, new structuralism and disappearance of form can be.

Developed mainly on international aesthetic conferences, we can emphasize a few general topics regarding ideas on architecture and urban design. However, main approach to the investigation of issues in question is positioned according to the ideas of inter/multi/trans cultural existence and development of aesthetic phenomenon in architecture and urban design in the contemporary world. The general intellectual atmosphere in which the debates are holding is created in regard to the conscious idea that one should learn from different cultural experiences. Need for comparison of aesthetic ideas emerging from various cultural interpretations and experience values become a powerful driving force in the research of everyday transformation of contemporary societies. Globalization and regionalization are side by side processes influencing development of new aesthetic visions, values, and experiences, and that idea has been deeply rooted into contemporary research approaches and processes. In that context, a number of investigations are launched trying to research how historical cultural particularities reflect and influence contemporary understanding of architecture and urban design in their cultural and trans cultural complexity. Existence of possible universal values, cultural differences and similarities in the interpretation of aesthetic phenomenon and meanings, are researched according to the contemporary processes of social and political transformations as a global fact. In that sense, particular value proves the investigation of perceptual issues as the basis for every aesthetic experience, aider as a pure physiological or cultural quality. It establishes the basis for a complex investigation of creativity as an aesthetic issue, particularly in the societies in the process of political, ideological, social and cultural transition, taking place in the last twenty years.

This process raises many issues and ideas trying to reevaluate ones, mostly ideologically, leading architectural and urban theories and practice. 
Domination of social housing, for example, in the general development of socialistic societies and their urban environment, is under new research scope trying to establish sustainable cultural and aesthetic values according to the contemporary conditions of political and ideological transition in which the majority of European states are living today. Witnessing an enormous activity and structural transformation of earlier carefully planned urban structures, the research of this interdisciplinary phenomenon seems inevitable. It is evident that needs of contemporary life and economy takes over the earlier established idealistic approach to modern urbanism, not only by interpolation of new buildings into the free space of the 'garden city', but also changing the functional, social, and cultural matrix of huge parts of urban structures. However, the questions related to the aspects of aesthetic evaluation of this phenomenon, should be based on various new experience values, not only as perceptual but also as new social and cultural qualities.

Learning from the past becomes a particularly important issue, especially when regarding the inter/multi/trans cultural position of architecture and urban environment. The goal of researching traditional urban matrix and architectural structures is not any more just to reach knowledge important for the preservation of that cultural heritage. It is now the research into issues of sustainability, cultural and ecological, formed by the long lasting experience of people living under particular historical and natural conditions, mainly lost in the era off international modernism. Transition of that experience into contemporary society proves as a very important one, reflecting on new modes of self sufficient build environment. However, these investigations are opening new reflections on aesthetic issues, which become a driving force in development of contemporary ideas on architecture and urban environment.

One of the processes challenging conventional aesthetic values regarding architecture is related to the change of existing functions of buildings. It seems that in this field practice surpass the theoretical discussion and research into aesthetic principles of this process. However, the complexity of the issue, particularly if related to the aspects of cultural and technological sustainability, is an argument for deeper research into all social and aesthetic consequences of this phenomenon. This issue is particularly urgent when talking about the industrial building heritage and its technological facilities. Especially in the countries under political, economical, and social transition, this kind of heritage disappears fast. Being not substantially researched, the cultural significance and aesthetic potential of this building practice is not recognized, causing its degradation or demolition. Research into this issue 
can also bring up new methodologies and approaches, aider in practice or education, which seems to be a substantially important field for contemporary architectural theory and aesthetics.

Contemporary aesthetics enters the field of creativity and epistemology in the search for the nature of aesthetic intention, as the foundation of every aesthetic activity. Complexity of this issue raises many questions regarding mainly the processes in forming concepts, leading to the final architectural and urban design appearance as a materialized cultural phenomenon. In that context, investigation in the field regarding the relationship between architectural creativity and education seems to be of interest, rising up questions looking on the process of conceptualizing ideas in a broader cultural context. The issues of interdisciplinary approach to the architectural education, the influence of other arts and design fields, of theories and fundamental perceptual and functional qualities, are recognized as the main factors in the process of defining the aesthetic intention, creative aspects, and concepts of design. They are at the same time tools for establishing the aspects of aesthetic evaluation, as the final step in the creative process. Awareness of such a structure of a creative process, can lead towards educational programs developing complex thinking and individual creative power, able to reflect on contemporary dynamic cultural environment.

Close to these issues, research into the relationship between architecture and consumerism and commercialism finds its important place. Not only that the research takes into the contemporary significance of these issues as an important part in the process of designing, but also as a manifestation of particular cultural value. It seems that consumerism and commercialism developed as a power controlling in some way the formation of aesthetic taste, respond, and needs of a majority in contemporary societies, becoming a strong force in the process of globalization. These issues are related to particular significance of contemporary media trough which ideas in architecture, art, and design are presented to the public, which brings them into the dynamic focus of the global information society. Does this process establish an global matrix of universal aesthetic values, or does it lead towards controlled everyday changeability of taste is still an open issue.

Only further research and discussion regarding the nature of aesthetic taste and how it forms in contemporary environment, can answer on questions related to the essence of creativity and its link to consumerism and commercialism. Can they help in generating values of high art or are they condemned to 
be identified as developers of mass produced kitsch in our everyday urban environment, are questions waiting for discussion. Entering also the field of ethics and its essential role in the development of aesthetic ideas, this issue proves to be a highly complex one. That way it also contributes to the research efforts regarding general environmental issues.

Research undertaken in the last decade, proves the importance of the environmental aesthetic issues. This field of interest is extremely complex, and it integrates different sub fields ranging from the issues regarding natural environment, through the research in ecology and its relationship with aesthetics, to urban and cultural environmental ideas. It also involves ideas relating new technologies and sustainability in architecture and urban environment, aider on the global level and regarding cultural and climate particularities. Relationship between these issues and aesthetical and ethical concepts seems to be primal research field, looking on aesthetics as a new power generating ideas which can bring sustainable urban development into function. Aesthetics in this context can be thought as a main component in the search for sustainable solutions because through it one can establish balance between technologies as products of human industrial capacities, ecology as a necessary component if the humanity wishes to survive, and cultural environment, global and particular, as the generator of future developments of ideas.

This general context of investigation deals with a number of questions related to the issues discussing relationship between city and nature trough their complex spatial, ecological, and cultural pervasions. The enormous development of cities creating urban environment with various, sometimes completely different concepts for each part of the same urban whole regarding their functional and historical particularities, brings up new issues and ways of interpretation of the essence of architecture, urban design, and nature. It also develops our understanding what the aesthetic can be when included into the process of a dynamic environmental development.

In this context, all aspects of contemporary commercialism, advertising and branding, find its place in our new experience of the city as a centre of economical power. However, it is not only the issue of relationship between architecture and new forms of public street advertising, often aggressive, which is in the focus of research into the perceptual phenomenon of merchant leading cities. There are different cultural issues and meanings regarding the multi/inter/trans cultural nature of contemporary megalopolis. The cultural exchange, particularly on the level of ordinary visitors to these cities, brings up 
extremely important issues, how and in what way we perceive and aesthetically reacting on cultural differences on a large urban scale.

New methodologies are established researching the possibility of urban regeneration through direct involvement of art as a form of public performance. It brings back the essential meaning of public spaces as places where the political, cultural, and social performance occur, particularly in and after renaissance time. Importance of these approaches raises from the fact that public art performance as a social and cultural phenomenon generates new aesthetic values within everyday urban environment. Further research in this field will open discussion of its limits and possibilities in the process of urban development.

Indicated research issues are proving the importance of aesthetic ideas regarding architecture and urban environment in their further development. Research of aesthetic ideas, which are essentially related to the cultural existence of men, opens the possibility for revalorization of theoretical positions on issues regarding essential processes of architectural creativity, perception of our contemporary built environment, and their further development. Minnesota Press, 1997.

Winters, Edward. Aesthetics \& Architecture. London:Continuum, 2007.

Baudrillard, Jean. Nouvel, Jean. The Singular Objects of Architecture. Minneapolis: University of Minnesota Press, 2002.

Berleant, Arnold. Carlson, Allen. The Aesthetics of Human Environments. Broadview Press, 2007. CD Proceedings of the International Conference Architecture and Ideology. ed. Vladimir Mako, Mirjana Roter Blagojević, Marta Vukotić Lazar, Belgrade: Faculty of Architecture University of Belgrade, Board of Ranko Radović Award, Association of Applied Arts Artists and Designers of Serbia, 2012.

Proceedings of the $5^{\text {th }}$ International Scientific Conference Architecture, Civil Engineering Modernity. Varna: Varna Free University, 2011.

Proceedings of the $4^{\text {th }}$ Mediterranean Congress of Aesthetics. Irbid: Yarmouk University, 2009.

Proceedings of the International Conference The Space in European Architecture - Tradition and Innovation. Varna: Varna Free University, 2009.

Proceedings of the ENHSA-EAAE Architectural Design Teachers' Network Meeting, Transactions 
on Architectural Education No. 35 Teaching and Experimenting With Architectural Design: Advances in Technology and Changes in Pedagogy. Lisbon: University Luisiada, 2007.

Proceedings of the $3^{\text {rd }}$ Mediterranean Congress of Aesthetics Imagination, Sensuality, Art. Ljubljana, Koper: Slovenian Society of Aesthetics, 2006.

Proceedings of the $2^{\text {nd }}$ Mediterranean Congress of Aesthetics Space and Memories. Association Tunisienne d'Esthetique et de Poietique, ATEP \& Maghreb Diffusion, 2005.

CD Proceedings of the $6^{\text {th }}$ International Conference of the European Academy of Design Design System Evolution. Bremen: University of the Arts, 2005.

CD Proceedings of the $1^{\text {st }}$ International Tropical Architecture Conference. Singapore: National University of Singapore, 2004.

CD Proceedings of the $15^{\text {th }}$ International Conference of Aestheticians. Tokyo: Institute of Aesthetics and Philosophy of Aret, Faculty of Letters University of Tokyo, 2003.

Proceedings of the mAAN $2^{\text {nd }}$ International Conference Towards Modern Asian Architecture. Singapore: National University of Singapore, 2002.

Proceedings of the $1^{\text {st }}$ Mediterranean Congress of Aesthetics. Annals for Aesthetics, Volume 41B, Athens: Panayotis \& Effie Michelis Foundation in collaboration with the Hellenic Society for Aesthetics, 2002.

International Yearbook of Aesthetics. International Association for Aesthetics. Online volumes on www.iaaesthetics.org. 
ESTETIKA U ARHITEKTURI:

SAVREMENA ISTRAŽIVA`KA PITANJA

\title{
Vladimir Mako
}

Cilj ovog članka je da pruži osvrt u vezi sa istraživanjima pitanja estetike vezanim za arhitekturu, urbano projektovanje, kao i životnu sredinu u opštem smislu. U tu svrhu, članak se fokusira na period poslednjih dvanaest godina, kao period intezivnih istraživanja navedenih pitanja korišćenjem novih filozofskih stavova i vrednosti interkulturalnosti. Čini se da je u tom periodu istraživanje estetike arhitekture pomereno u složena interdisciplinarna polja razvijajući nove teorijske ideje a u isto vreme obogaćujući procese kreativne prakse.

KLJUČNE REČI: ESTETIKA, ARHITEKTURA, URBANO PROJEKTOVANJE, ŽIVOTNA SREDINA, ISTRAŽIVANJE

UMETNOST I ESTETIKA: TRI SKORAŠNJE PERSPEKTIVE

\begin{abstract}
Aleš Erjavec
Autor skicira razvoj odnosa između umetnosti i estetike u nedavnoj prošlosti. Kao svoju polaznu tačku on uzima stanovište koje su umetnici ustanovili šezdesetih godina u odnosu na filozofsku estetiku. Po njegovom mišljenju 1980 godina je predstavljala istorijski početak što se tiče transformacija i u umetnosti i u filozofiji. On zatim razmatra tri teorije umetnosti i estetike „relacionu estetiku“ Nikolasa Burioda iz devedestih, estetski projekat Žaka Ransijera iz naredne decenije i najskoriju ,teoriju savremene umetnosti“ koju je razvio Teri Smit. Po autorovom mišljenju, ove tri teorije estetike i umetnosti ne samo da opovrgavaju prožimajuće mišljenje da je savremena estetika shvaćena kao filozofija umetnosti još jednom odvojena od savremene umetnosti i sveta umetnosti, ali isto tako jasno ispoljavaju njihov faktički značaj i uticaj u savremenim diskusijama o umetnosti.
\end{abstract}

KLJUČNE REČI: UMETNOST, ESTETIKA, RELACIONA ESTETIKA, ŽAK RANSIJER, TERI SMIT, SAVREMENA UMETNOST

ARHITEKTURA I FILOZOFIJA

Odnosi, potencijalnosti i kriti`na mesta

\section{Miško Šuvaković}

U raspravi "ARHITEKTURA I FILOZOFIJA / odnosi, potencijalnosti i kritična mesta" biće reči o pojmovima "filozofija arhitekture" i "estetika arhitekture". Biće uvedene razlike između tradicionalne i savremene filozofije i estetike arhitekture. U posebnom potpoglavlju se razmatra status "teorija" i 